\title{
3-D geological modelling of the Egebjerg area, Denmark, based on hydrogeophysical data
}

\author{
Flemming Jørgensen, Rasmus Rønde Møller, Peter B.E. Sandersen and Lars Nebel
}

Contamination of groundwater with pesticides and nitrate has compelled the Danish Government to launch a major hydrogeological mapping programme covering about $40 \%$ of the land area of Denmark. Numerous geophysical surveys are currently being carried out in order to acquire the necessary data. These new data are crucial for the 3-D geological models that are used in the planning of future water supply and landuse. Normally, site-specific groundwater protection zones (Thomsen et al. 2004) are based on groundwatermodelled catchment areas for each well, but proper 3-D geological models are needed in order to create a valid basis for the groundwater models. Since most of the Danish nearsurface geology is complex, a full geological understanding is required combined with in-depth interpretation of geological and geophysical data.

Much research has dealt with geophysical mapping and numerical groundwater modelling, but only limited research has combined these topics for geological modelling. Prior to geophysical mapping, groundwater models were based on simple data extraction from well databases without inclusion of geophysical data. In the following, a concept for detailed 3-D geological modelling with hydrogeophysical data is presented for a specific area.

\section{Data and study area}

The $150 \mathrm{~km}^{2}$ area for modelling is located in Jylland (Fig. 1). The surface is dominated by clayey tills and reaches an elevation of more than $160 \mathrm{~m}$ above sea level.

Prior to the geophysical survey, the only useful data for a geological model in this area came from boreholes. Lithological descriptions were only available for $50-75 \%$ of the boreholes, and the boreholes were too widely spaced to provide an overview of the subsurface geology. Hence a detailed geological model could not be constructed.

Two geophysical methods were employed in the model area, the airborne transient electromagnetic method (SkyTEM; Sørensen \& Auken 2004) and the pulled array continuous electrical sounding method (PACES; Sørensen 1996). The SkyTEM survey was to map the deeper sections of the subsurface down to depths of $200 \mathrm{~m}$, while the PACES survey focused on the uppermost $25 \mathrm{~m}$. Both surveys were con- ducted along lines with a spacing of $250 \mathrm{~m}$. The heterogeneity in the shallowest parts of the subsurface is commonly too great to obtain a proper correlation between the PACES survey lines, but at larger depths a better correlation is achieved by the SkyTEM data. By combining SkyTEM and borehole data a solid basis for geological modelling was obtained in the study area.

\section{Model concept}

A three-step approach for 3-D geological modelling used for hydrogeological purposes has recently been developed in Denmark (Jørgensen et al. 2008). With this approach the modelling both ensures a thorough data interpretation and utilises the potential that lies in establishing an understanding of the geological history. The approach divides the geological model into three submodels:

1. A general, conceptual geological model which is primarily descriptive and imaged in conceptual cross-sections. The conceptual geological model is based on a review of former work and existing literature.

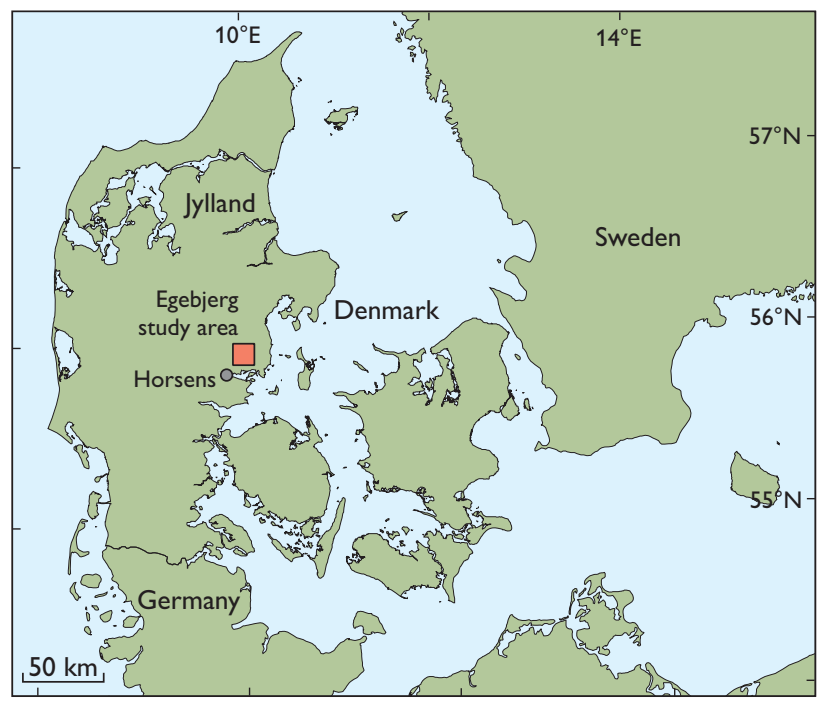

Fig. 1. Map of Denmark showing the location of the study area, Egebjerg, north of the city of Horsens. 

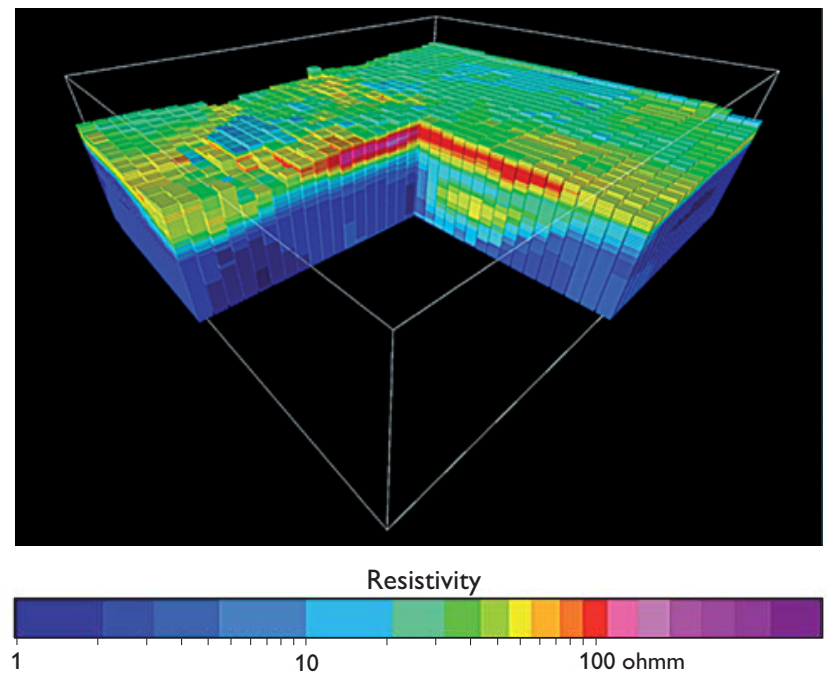

Fig. 2. Selected section of the SkyTEM resistivity voxel grid. Cell size: 100 $\times 100 \times 5 \mathrm{~m}$.

2. A 3-D geological model, which is intended to serve as a geological database for a given model area and may contain all kinds of geological information, both lithological and stratigraphical. The 3-D model is not necessarily established in areas with poor data coverage.

3. A 3-D hydrostratigraphic model, which is intended to serve as the input for numerical groundwater models. This model is based on the 3-D geological model but focuses on lithological and hydraulic parameters. Normally it will cover the entire model space, incorporating a 'best guess' in areas with poor data coverage.

Traditional 3-D geological models for hydrogeological purposes are constructed as layer-cake models, where the layers are defined as the volume between two surfaces. Elements in such models are thus defined by bounding surfaces. The surfaces are defined by digitised points and/or interpolated grids from the digitised points. Such models do not require advanced modelling software, but critical restrictions may arise in areas of complex geology where layer variations may be difficult or impossible to model (Turner 2006).

As the geology in Denmark is rarely organised as welldefined layers and hence cannot be properly described in a layer-based model, a different approach is needed. The challenge is to resolve heterogeneity to a degree that meets the demands of the user, e.g. numerical groundwater modelling. One way to do this is by 'voxel' (voxel = volumetric pixel) modelling (e.g. Turner 2006).

Due to the high complexity in the Egebjerg area voxel modelling has therefore been implemented and tested here. The voxel discretisation is $100 \times 100 \mathrm{~m}$ in the $\mathrm{X}-\mathrm{Y}$ direction and $5 \mathrm{~m}$ in the $\mathrm{Z}$ direction resulting in a 3-D voxel grid

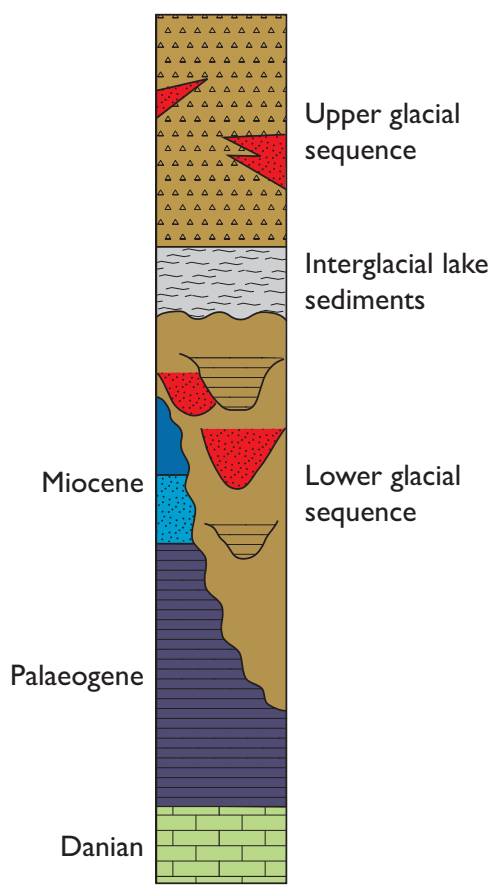

Fig. 3. Stratigraphical log for the model area. The thickness of the entire section corresponds to about $200 \mathrm{~m}$. For explanation see the text.

composed of 1.5 million voxels organised in 74 voxel layers. As the SkyTEM data cover large parts of the area, a resistivity grid with discretisation and dimensions identical to the voxels is generated, basically supplying the voxel grid with a resistivity value (Fig. 2). The voxel model is supplemented by a number of layer boundaries modelled as surfaces. These layer boundaries are based on digitised point swarms and interpolated to contoured 2-D grids. The software package GeoScene 3D (I-GIS 2010) is used for the modelling.

The Egebjerg model follows the three-step approach for geological modelling as described above, but minor adjustments were required in order to make use of the voxel model approach. The chosen model concept is as follows:

1. A general, conceptual geological model identical to the one described in the three-step approach above.

2. A 3-D stratigraphical model, in which the geological history of the model area is in focus. Geological elements, structures and stratigraphical boundaries are modelled and subdivided according to their origin. The geological elements comprise boundaries such as Top Chalk, Top Palaeogene, erosional unconformities, stratigraphical units such as Palaeogene and Miocene, buried tunnel valleys, glaciotectonic complexes and interglacial units. This model is a combined layer-based and voxel model and is generally comparable to the 3-D geological model within the three-step approach. 


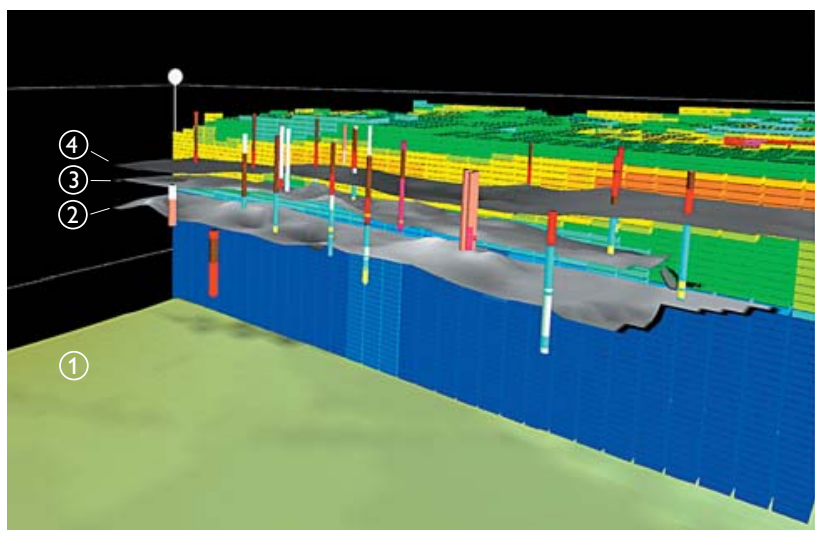

Fig. 4. 3-D stratigraphical model section showing from below the boundaries of Top Chalk (1: green surface), Top Palaeogene (2: lower grey surface), an internal Miocene boundary (3: middle grey surface) and the preQuaternary surface (4: upper grey surface). Boreholes and the SkyTEM resistivity grid are also shown. Vertical exaggeration: 5 times.

3. A 3-D lithofacies model that is entirely voxel based, and in which all voxels are allocated an attribute for lithofacies. The model is based on the 3-D stratigraphical model. A challenge here is to estimate the lithofacies in heterogeneous areas or areas with poor data coverage. A qualitative approach for uncertainty assessment of the interpretations is used and attributed to each voxel in order to visualise the overall model uncertainties (Sandersen 2008). This is important in connection with the subsequent implementation in a numerical groundwater model. The uncertainty approach is also applied to the 3-D stratigraphical model.

\section{Model results}

The geological modelling resulted in the stratigraphical log shown in Fig. 3. It comprises a Tertiary sequence followed by glacial and interglacial sediments above the pre-Quaternary surface. This surface unconformably cuts layers of Miocene clay, silt and sand, and Palaeogene clay, which in turn overlie Danian limestone at depths of about $200 \mathrm{~m}$. Only one borehole in the area reaches the limestone, but in some areas, where the SkyTEM soundings penetrate the Palaeogene clay, the limestone is seen as a layer with slightly elevated resistivity values. The Palaeogene clay shows high electrical conductivity and responds as a distinct and well-defined surface in the SkyTEM data. Erosional remnants of Miocene deposits are only found in minor parts of the study area. A model section showing parts of the pre-Quaternary sequence is shown in Fig. 4.

The Quaternary sequence is divided into an upper glacial/ interglacial sequence and a lower glacial sequence. Several

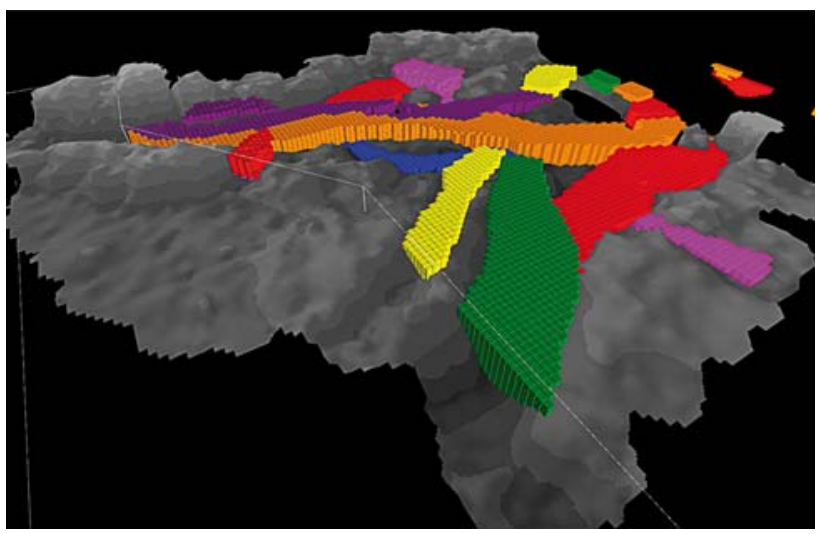

Fig. 5. A series of buried tunnel valleys modelled by voxels in the 3-D stratigraphical model: Each colour represents one buried tunnel valley. The Palaeogene surface is shaded in grey. Vertical exaggeration: 5 times.

buried valleys are present within the lower glacial sequence, and at least four generations occur here. The valleys are interpreted as tunnel valleys (sensu Jørgensen \& Sandersen 2006), and the sequence comprises a complex setting of cross-cutting valleys that have repeatedly been incised and filled. The valleys are primarily filled with till and glaciolacustrine clay but coarse meltwater deposits also occur. The valleys are modelled by voxels due to their high spatial complexity (Fig. 5).

In the SkyTEM data, the lower glacial and upper glacial/ interglacial sequences are divided by an apparently widespread, gently undulating resistivity boundary that is considered to be an erosional unconformity. This unconformity appears as a widespread and more or less horizontal contrast in the resistivity data; with alternating high and low resistivity values on each side of the boundary. Above the unconformity a unit of interglacial diatomaceous lake sediments is found in boreholes. Pollen analyses show that these sediments were deposited during the Holsteinian interglacial (Odgaard 2010), and the erosional unconformity and the glacial sequence below, including most of the tunnel valleys, are therefore of Elsterian age or older.

Some subareas in the study area are glaciotectonically deformed. This is seen where Tertiary clay is found above glacial sediments in the boreholes. These large rafts of Palaeogene clay, only indicated by a few boreholes, are well resolved in the SkyTEM data. The deformed layers are in some places found inside the buried tunnel valleys showing that the deformation took place after the valley formation.

The 3-D stratigraphical model as described above is used as the basis for the construction of the 3-D lithofacies model. Some units in the 3-D stratigraphical model are more or less directly converted to lithofacies, but other units are subdivided, merged or reordered prior to incorporation into the 

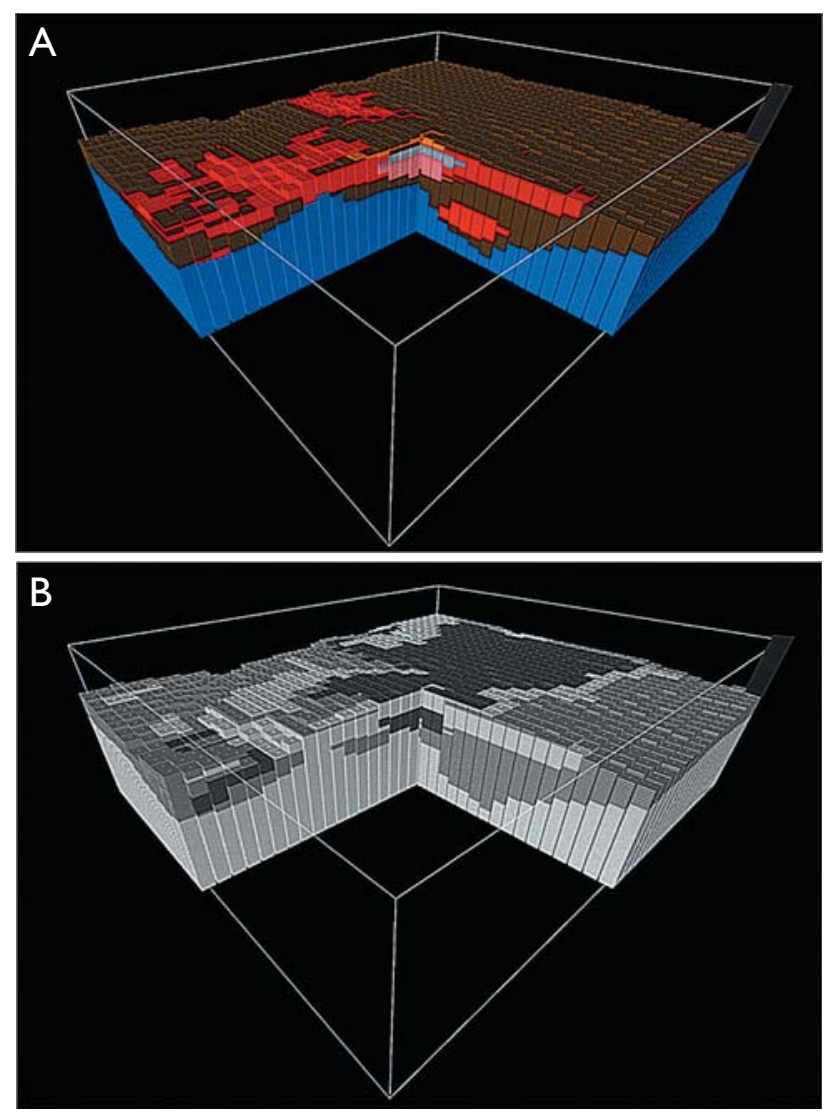

Fig. 6. Selected section of the 3-D lithofacies model (identical to Fig. 2). A: The lithofacies voxel model. Blue: Palaeogene clay. Dark brown: clay till. Light brown: sand till. Red: meltwater sand/gravel. Light red: sand. Grey: diatomite. B: Uncertainty of the lithofacies model. Light grey: low uncertainty. Grey: medium uncertainty. Dark grey: high uncertainty. Vertical exaggeration: 3 times.

3-D lithofacies model. A selected part of the model and its corresponding uncertainty is shown in Fig. 6.

\section{Concluding remarks}

In the Egebjerg study area detailed stratigraphical and lithological information has been obtained by studying 3-D resistivity grids based on the SkyTEM data and evaluating these against borehole data. In order to make full use of the new information for numerical groundwater modelling or for other purposes, the data have been incorporated in a 3-D geological model. The 3-D modelling was carried out in two steps, where two differently focused 3-D models were constructed. First a 3-D model focusing on stratigraphy was constructed and subsequently, based on this, a 3-D lithofacies model was constructed. This approach enables in-depth geological interpretation and secures maximum utilisation of the large data sets. The heterogeneous geology revealed by the SkyTEM data cannot be sufficiently incorporated into a simple layer-based model, and a combination of a voxel and a layer model has therefore proven successful for the Egebjerg study area.

\section{Acknowledgements}

The project is supported by Environment Centre Aarhus. We thank Klaus Petersen and Stine Rasmussen for helpful discussions.

\section{References}

I-GIS 2010: GeoScene 3D. http://www.i-gis.dk/Default.aspx?tabid=132. Jørgensen, F. \& Sandersen, P.B.E. 2006: Buried and open tunnel valleys in Denmark - erosion beneath multiple ice sheets. Quaternary Science Reviews 25, 1339-1363.

Jørgensen, F., Kristensen, M., Højberg A.L., Klint, K.E.S., Hansen, C., Jordt, B.E. Richardt, N. \& Sandersen, P. 2008: Opstilling af geologiske modeller til grundvandsmodellering. Geo-Vejledning 3, 176 pp. Copenhagen: Geological Survey of Denmark and Greenland.

Odgaard, B. 2010: Pollenanalytisk datering af ferskvandsaflejring i DGU nr. 107.733, Horsens Vandværk, 2 pp. Unpublished report, Aarhus Universitet, Danmark.

Sandersen, P.B.E. 2008: Uncertainty assessment of geological models - a qualitative approach. In: Refsgaard, J.C. et al. (eds): Calibration and reliability in groundwater modelling: credibility of modelling. International Association of Hydrological Sciences Publication 320, 345-349.

Sørensen, K. 1996: Pulled array continuous electrical profiling. First Break 14, 85-90.

Sørensen, K.I. \& Auken, E. 2004: SkyTEM - a new high-resolution helicopter transient electromagnetic system. Exploration Geophysics 35, 191-199.

Thomsen, R., Søndergaard, V.H. \& Sørensen, K.I. 2004: Hydrogeological mapping as a basis for establishing site-specific groundwater protection zones in Denmark. Hydrogeology Journal 12, 550-562.

Turner, A.K. 2006: Challenges and trends for geological modelling and visualisation. Bulletin of Engineering Geology and the Environment 65, 109-127.

\section{Authors' addresses}

F.J. \& R.R.M., Geological Survey of Denmark and Greenland, Øster Voldgade 10, DK-1350 Copenhagen K, Denmark. E-mail:flj@geus.dk

P.B.E.S., Grontmij | Carl Bro A/S, Dusager 12, DK-8200 Arhus N, Denmark.

L.N., I-GIS, Voldbjergvej 14, 2., DK-8240 Risskov, Denmark. 